\title{
A STUDY ON NUTRITIONAL STATUS OF TRACE MINERALS OF CATTLE IN JAVA IN INDONESIA
}

\author{
H. Kumagai ${ }^{1}$, N. Ishida, M. Katsumata, H. Yano, \\ R. Kawashima and J. Jachja ${ }^{2}$ \\ Department of Animal Science, Faculty of Agriculture, \\ Kyoto University, Kyoto-shi 606, Japan
}

\begin{abstract}
Summary
The nutritional status of trace minerals in cattle of Java in Indonesia was investigated by evaluating $\mathrm{Cu}, \mathrm{Fe}, \mathrm{Mo}, \mathrm{Zn}$ and $\mathrm{Mn}$ concentrations in diets and livers, and $\mathrm{Cu}$ and $\mathrm{Zn}$ concentrations in blood plasma. Investigations were conducted on Jonggol (West Java), Malang (East Java) and Mojokerto (East Java) in both the rainy and the dry seasons in 1988. In Jonggol, low Cu concentrations in diets showing $7.1 \mathrm{mg} / \mathrm{kg}$ in the rainy season and $10.9 \mathrm{mg} / \mathrm{kg}$ in the dry season were observed and all plasma samples showed $\mathrm{Cu}$ concentrations below the critical level $(0.65 \mu \mathrm{g} / \mathrm{ml})$. Thirty percent of the liver samples in Malang and $54 \%$ of those in Mojokerto showed lower $\mathrm{Cu}$ concentrations than the critical level $(75 \mathrm{mg} / \mathrm{kg}$ on a dry matter basis). Fe concentrations in diets from the three regions showed a wide variation of values ranging from 249 to $30,000 \mathrm{mg} / \mathrm{kg}$. A large amount of Fe was accumulated in livers from Malang and Mojokerto, giving average concentrations of $498 \mathrm{mg} / \mathrm{kg}$. Zn concentrations in diet and plasma samples were close to the borderline and some $\mathrm{Zn}$ concentration in these samples showed deficient levels. Mo and Mn concentrations in diets and livers showed normal levels.

(Key Words: Java in Indonesia, Cattle, Dietary $\mathrm{Cu}, \mathrm{Fe}, \mathrm{Mo}, \mathrm{Zn}$ and $\mathrm{Mn}$, Liver $\mathrm{Cu}, \mathrm{Fe}, \mathrm{Mo}, \mathrm{Zn}$ and $\mathrm{Mn}$, Plasma $\mathrm{Cu}$ and $\mathrm{Zn}$ )
\end{abstract}

\section{Introduction}

Most beef cattle production in tropical Asia relies on native grasses and agricultural by-products. Under such conditions cattle have often suffered from mineral imbalances. A previous study (Kumagai et al., 1990) indicated that a low $\mathrm{P}$ concentration and a high Ca:P ratio in diets were likely to induce low plasma inorganic phosphorus concentration in cattle from Jonggol in Java. Recently other investigations in tropical Asia have indicated imbalances of trace mineral concentrations in diets and tissues such as blood and liver. Vijchulata et al. (1983) reported low $\mathrm{Cu}$ and wide variety of $\mathrm{Fe}$ concentrations in diets and low $\mathrm{Cu}$ concentrations in blood plasma and livers of cattle from Central Thailand. Hayashi et al. (1985) indicated low $\mathrm{Cu}$ concentrations in diets and blood plasma of cattle from some pastures around Medan

\footnotetext{
${ }^{1}$ Address reprint requests to Dr. H. Kumagai, Department of Animal Science, Faculty of Agriculture, Kyoto University, Kyoto-shi 606, Japan.

${ }^{2}$ Department of Animal Nutrition and Feed Science, Bogor Agricultural University, Bogor, Indonesia.

Received October 4, 1989

Accepted January 29, 1990
}

in Sumatra. However, available information concerning the trace mineral status of cattle in tropical Asia is limited and the relationship between mineral concentrations of diets and animal tissues is still obscure.

In the present study, the nutritional status of trace minerals of cattle in Java, Indonesia was examined by evaluating trace mineral concentrations in diet, liver and blood plasma samples. Se and Co status of cattle in the country will be discussed in another report.

\section{Materials and Methods}

Description of cattle, location and season for sample collection, methods for the blood and diet sample collection and preparation of samples are described by Kumagai et al. (1990).

\section{Collection of liver samples}

About $50 \mathrm{~g}$ of liver samples were collected from lobus caudatus of the livers of cattle which were slaughtered in Malang and Mojokerto. Samples were washed by saline, put in clean polyvinyl bags and frozen with dry ice. They were freeze-dried and ground by a ball mill after they were brought to Japan. 


\section{Analytical methods}

One gram of each diet and liver sample and one milliliter of each plasma sample were digested in $10 \mathrm{ml}$ of a $4: 1$ mixture of $60 \%$ nitric and perchloric acids. The concentrations of $\mathrm{Cu}, \mathrm{Fe}, \mathrm{Mo}, \mathrm{Zn}$ and $\mathrm{Mn}$ were measured by atomic absorption spectrophotometry.

\section{Statistical analysis}

The mineral concentrations in diet, liver and plasma samples were statistically analyzed as a following mathematical model:

$$
Y=\mu+R i+S j+(R S) i j+E i j k
$$

where

$$
\begin{aligned}
\mathrm{Y} & =\text { each mineral concentration } \\
\mu & =\text { the overall mean } \\
\mathrm{Ri} & =\text { the effect associated with sampling }
\end{aligned}
$$

region

$$
\begin{aligned}
\mathrm{Sj}= & \text { the effect associated with sampling } \\
& \text { season } \\
(\mathrm{RS}) \mathrm{ij}= & \text { the interaction effect between sampl- } \\
& \text { ing region and season }
\end{aligned}
$$

Eijk = residual

All statistical analyses were conducted by using General Linear Model (GLM) procedure of Statistical Analysis System (SAS) program package (Barr et al., 1985). The null hypothesis that a pair of least square means in each effect is equal was

\begin{tabular}{|c|c|c|c|c|c|c|c|c|}
\hline \multirow{2}{*}{ Region } & \multirow{2}{*}{ Season } & \multirow{2}{*}{ Species of diets } & \multirow{2}{*}{$\begin{array}{c}\text { Number of } \\
\text { samples }\end{array}$} & $\mathrm{Cu}$ & $\mathrm{Fe}$ & Mo & $\mathrm{Zn}$ & $\mathrm{Mn}$ \\
\hline & & & & \multicolumn{5}{|c|}{$\ldots \mathrm{mg} / \mathrm{kg}$ on a dry matter basis } \\
\hline \multirow[t]{8}{*}{ Jonggol } & Rainy & Cynodon dactylon & 2 & 9.8 & 8,610 & 2.41 & 51.3 & 170 \\
\hline & & Imperata cylindrica & 2 & 3.9 & 462 & 0.41 & 20.6 & 21 \\
\hline & & Oplismenus undalatifolius & 2 & 8.3 & 3,770 & 1.23 & 37.8 & 173 \\
\hline & & Paspalum dilatatum & 2 & 5.5 & 372 & 0.27 & 32.1 & 121 \\
\hline & & Setaria sphacelata & 1 & 8.9 & 249 & 0.61 & 48.8 & 358 \\
\hline & Dry & Cynodon dactylon & 1 & 9.6 & 2,100 & 2.01 & 51.3 & 303 \\
\hline & & Imperata cylindrica & 1 & 6.8 & 905 & 1.45 & 45.8 & 70 \\
\hline & & Setaria sphacelata & 2 & 13.5 & 545 & 0.98 & 56.5 & 403 \\
\hline \multirow[t]{8}{*}{ Malang } & Rainy & corn stover & 2 & 13.4 & 6,720 & 0.54 & 34.5 & 124 \\
\hline & & Cynodon dactylon & 2 & 13.9 & 4,770 & 1.67 & 49.0 & 150 \\
\hline & & sweet potato vine & 1 & 36.4 & 11,600 & 0.28 & 32.9 & 236 \\
\hline & & chopped native grass ${ }^{\mathrm{a}}$ & 2 & 13.4 & 2,460 & 0.78 & 25.8 & 104 \\
\hline & Dry & corn stover & 1 & 9.7 & 1,607 & 1.59 & 45.6 & 46 \\
\hline & & rice straw & 2 & 6.2 & 957 & 1.15 & 42.4 & 559 \\
\hline & & sugar cane leaf & 2 & 10.2 & 2,370 & 1.41 & 29.4 & 64 \\
\hline & & chopped native grass $^{\mathrm{a}}$ & 3 & 13.0 & 2,570 & 1.08 & 42.3 & 140 \\
\hline \multirow[t]{8}{*}{ Mojokerto } & Rainy & chinese yam skin & 1 & 24.6 & 30,000 & 0.28 & 54.5 & 384 \\
\hline & & Cynodon dactylon & 1 & 10.2 & 2,620 & 3.06 & 46.3 & 90 \\
\hline & & sweet potato vine & 1 & 19.0 & 2,670 & 0.94 & 31.4 & 71 \\
\hline & & chopped native grass ${ }^{a}$ & 4 & 21.9 & 10,000 & 1.27 & 69.5 & 199 \\
\hline & Dry & corn stover & 1 & 5.4 & 540 & 0.33 & 10.9 & 79 \\
\hline & & Cynodon dactylon & 2 & 12.0 & 2,330 & 0.95 & 54.4 & 68 \\
\hline & & sugar cane leaf & 1 & 4.3 & 933 & 2.03 & 18.5 & 34 \\
\hline & & chopped native grass $^{\mathrm{a}}$ & 2 & 18.2 & 6,304 & 1.74 & 46.7 & 308 \\
\hline
\end{tabular}
tested.

\section{Results}

\section{Mineral concentrations in diets}

Species and mineral concentrations of diet samples are presented in table 1. Mean mineral concen-

TABLE 1. SPECIES AND MINERAL CONCENTRATIONS OF DIETS FROM THREE REGIONS IN JAVA OF INDONESIA

aspecies are undefined. 
trations of diet samples and results of statistical analyses are presented in table 2 . The $\mathrm{Cu}$ concentrations in diets ranged from 3.9 to $36.4 \mathrm{mg} / \mathrm{kg}$ and a significant difference was found between Jonggol and Mojokerto $(\mathrm{p}<0.01)$. The Fe concentrations in diets showed a wide variation of values ranging from 249 to $30,000 \mathrm{mg} / \mathrm{kg}$ and the overall mean of $\mathrm{Fe}$ concentration was $4,400 \pm$ 6,990 (mean $\pm \mathrm{SD}$ ) $\mathrm{mg} / \mathrm{kg}$. The Mo and $\mathrm{Zn}$ concentrations in diets ranged from 0.27 to $3.06 \mathrm{mg} /$ $\mathrm{kg}$ and from 10.9 to $69.5 \mathrm{mg} / \mathrm{kg}$, respectively. An analysis of $\mathrm{Mn}$ concentrations showed a wide variation of values ranging from 21 to $559 \mathrm{mg} / \mathrm{kg}$ and the overall mean of Mn concentration was $181 \pm$

TABLE 2. MINERAL CONCENTRATIONS IN DIETS FROM THREE REGIONS IN JAVA OF INDONESIA

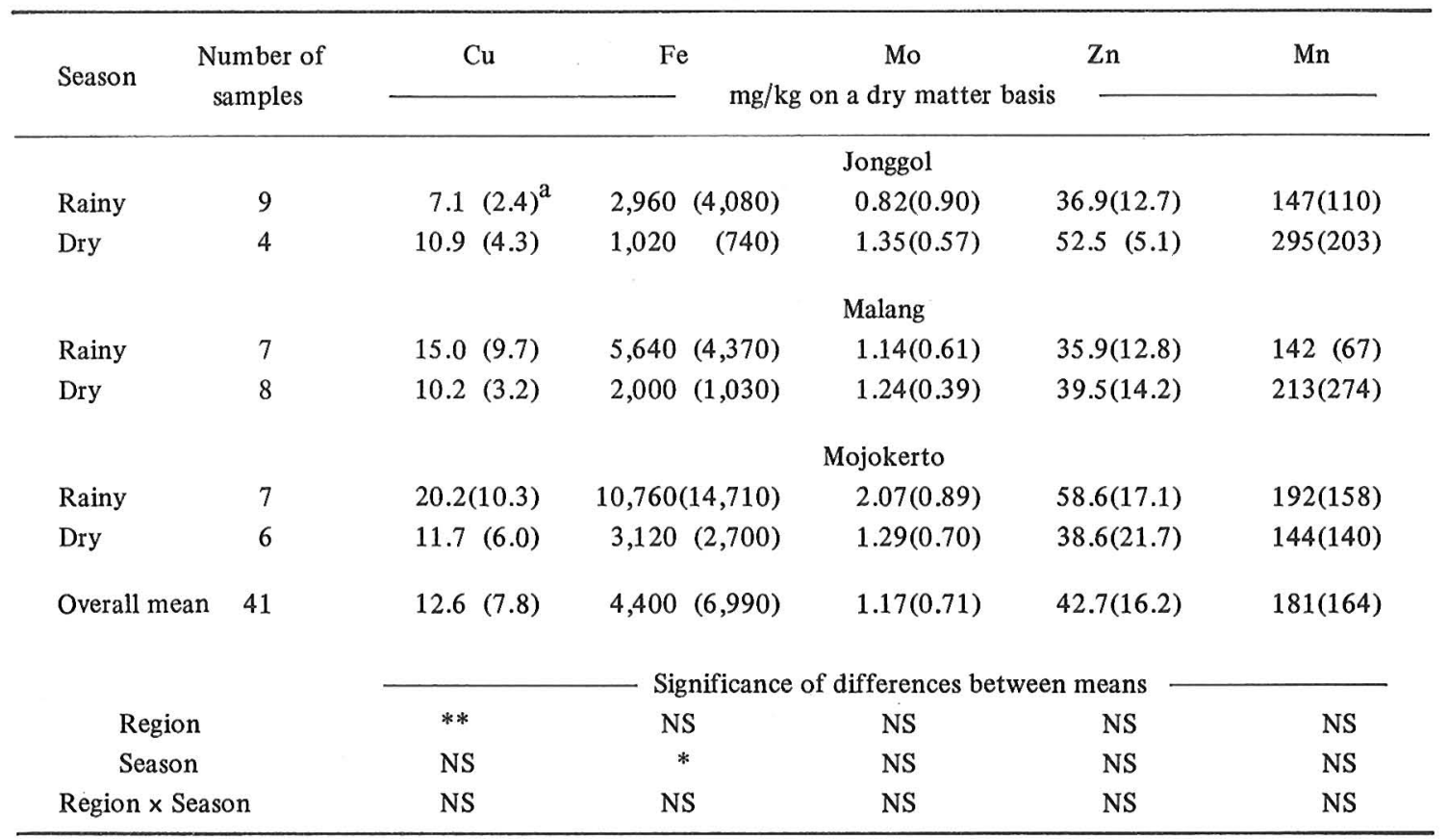

$* \mathrm{p}<0.05, * * \mathrm{p}<0.01$, NS not significant

a mean (SD)

$164 \mathrm{mg} / \mathrm{kg}$.

\section{Mineral concentrations in livers}

Results are presented in table 3. The liver $\mathrm{Cu}$ concentrations were extremely variable from 9 to $369 \mathrm{mg} / \mathrm{kg}$ and the overall mean of $\mathrm{Cu}$ concentrations was $123 \pm 90$ (mean $\pm \mathrm{SD}$ ) $\mathrm{mg} / \mathrm{kg}$. The liver $\mathrm{Fe}$ concentration showed a wide variety of values ranging from 211 to $1,223 \mathrm{mg} / \mathrm{kg}$ and the overall mean of $\mathrm{Fe}$ concentrations was $498 \pm 205 \mathrm{mg} / \mathrm{kg}$. The overall mean of Mo, $\mathrm{Zn}$ and Mn concentrations in livers were $2.98 \pm 0.59,145 \pm 30$ and 9.08 $\pm 1.93 \mathrm{mg} / \mathrm{kg}$, respectively.

\section{Mineral concentrations in blood plasma}

Results are presented in table 4. The mean plasma $\mathrm{Cu}$ concentration in Jonggol was $0.22 \mu \mathrm{g} /$ $\mathrm{ml}$ in both rainy and dry seasons. The plasma $\mathrm{Cu}$ concentrations in Jonggol were significantly lower than those from Malang and Mojokerto $(p<0.01)$. The overall mean of plasma $\mathrm{Zn}$ concentrations was $0.87 \mu \mathrm{g} / \mathrm{ml}$ and no significant difference was observed among regions and between seasons.

\section{Discussion}

Because of a limited number of diet samples and a wide variation of dietary mineral concentrations, it is difficult to estimate the mineral concentrations in diets which were actually fed by cattle. However, the $\mathrm{Fe}$ concentrations in diet samples from three regions are higher than those from Japan which have been examined in a previous study. Takahashi (1978) reported that the Fe con- 
TABLE 3. MINERAL CONCENTRATIONS IN LIVERS OF CATTLE FROM TWO REGIONS IN JAVA OF INDONESIA

\begin{tabular}{|c|c|c|c|c|c|c|}
\hline \multirow{2}{*}{ Season } & \multirow{2}{*}{$\begin{array}{c}\text { Number of } \\
\text { samples }\end{array}$} & $\mathrm{Cu}$ & \multicolumn{2}{|c|}{$\begin{array}{l}\mathrm{Fe} \\
-\mathrm{mg} / \mathrm{kg} \text { on a dry matter basis }\end{array}$} & $\mathrm{Zn}$ & $\mathrm{Mn}$ \\
\hline & & & & Malang & & \\
\hline Rainy & 25 & $148(106)^{\mathrm{a}}$ & $541(230)$ & $2.72(0.58)$ & $161(35)$ & $9.46(2.12)$ \\
\hline \multirow[t]{2}{*}{ Dry } & 25 & $156(90)$ & $555(205)$ & $2.91(0.64)$ & $135(25)$ & $8.93(1.31)$ \\
\hline & & \multicolumn{5}{|c|}{ Mojokerto } \\
\hline Rainy & 25 & $99(66)$ & $440(189)$ & $3.15(0.53)$ & $139(27)$ & $10.40(1.96)$ \\
\hline Dry & 25 & $89(79)$ & $441(174)$ & $3.15(0.55)$ & $144(28)$ & $7.49(1.01)$ \\
\hline \multirow[t]{2}{*}{ Overall mean } & 100 & $123(90)$ & $498(205)$ & $2.98(0.59)$ & $145(30)$ & $9.08(1.93)$ \\
\hline & & & \multicolumn{3}{|c|}{ Significance of differences between means } & \\
\hline \multicolumn{2}{|l|}{ Region } & $* *$ & $*$ & $* *$ & NS & NS \\
\hline \multicolumn{2}{|l|}{ Season } & NS & NS & NS & NS & $* *$ \\
\hline \multicolumn{2}{|c|}{ Region $\times$ Season } & NS & NS & NS & $* *$ & $* *$ \\
\hline
\end{tabular}

TABLE 4. PLASMA MINERAL CONCENTRATIONS OF CATTLE FROM THREE REGIONS IN JAVA OF INDONESIA

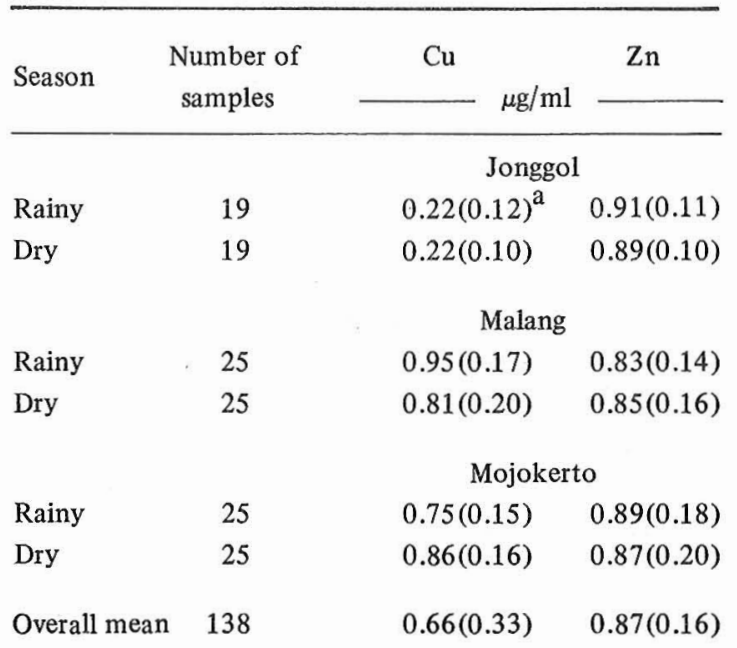

Significance of differences between means

$\begin{array}{ccc}\text { Region } & * * & \text { NS } \\ \text { Season } & \text { NS } & \text { NS } \\ \text { Region } \times \text { Season } & * * & \text { NS }\end{array}$

$* * p<0.01$, NS not significant

a mean (SD) centrations in pasture samples from 76 regions in Japan ranged from 52 to $322 \mathrm{mg} / \mathrm{kg}$. The high Fe concentrations of diet samples in this study might be induced by two causes, i.e., Fe accumulation in plant and soil contamination. Under the reducing conditions of a high and fluctuating soil water table, especially in the presence of oxidisable organic matter, plant-available ferrous iron greatly increases (Islam et al., 1954). An Fe concentration in soil is much higher than that in forage. Leech et al. (1987) suggested that the high Fe concentrations in pasture from some regions in England might be due to soil contamination. Further investigations should be made to explain the cause of high $\mathrm{Fe}$ concentrations in diets.

Campbell et al. (1974) reported that the liver $\mathrm{Fe}$ concentrations in calves, which were fed with a diet containing $1,981 \mathrm{mg} / \mathrm{kg}$ of $\mathrm{Fe}$ for 202 days, increased to $460 \mathrm{mg} / \mathrm{kg}$. The mean $\mathrm{Fe}$ concentrations in diet samples from Malang and Mojokerto were higher than $2,000 \mathrm{mg} / \mathrm{kg}$ (table 2) and the overall mean of $\mathrm{Fe}$ concentrations in liver samples from Malang and Mojokerto were $498 \mathrm{mg} / \mathrm{kg}$ (table 3). It is considered that the high liver $\mathrm{Fe}$ concentrations in Malang and Mojokerto may have been caused by the high $\mathrm{Fe}$ concentrations in diets from these regions. 
Harada et al. (1976) reported that the liver $\mathrm{Cu}$ concentrations of steers fed a diet with $295 \mathrm{mg} / \mathrm{kg}$ of $\mathrm{Fe}$ were lower than those of steers fed a diet with $11 \mathrm{mg} / \mathrm{kg}$ of $\mathrm{Fe}$. Campbell et al. (1974) reported that the liver $\mathrm{Cu}$ concentrations of calves fed a diet with $1,981 \mathrm{mg} / \mathrm{kg}$ of $\mathrm{Fe}$ for 202 days decreased to $7 \mathrm{mg} / \mathrm{kg}$. These studies indicated that a high level of $\mathrm{Fe}$ in diets influenced $\mathrm{Cu}$ metabolism in cattle. In the present study, $30 \%$ of the liver samples in Malang and 54\% of those in Mojokerto showed $\mathrm{Cu}$ concentrations below $75 \mathrm{mg} / \mathrm{kg}$ which is the critical level recommended by McDowell et al. (1983). The lowest $\mathrm{Cu}$ concentration was only $9 \mathrm{mg} / \mathrm{kg}$ in Malang and $10 \mathrm{mg} / \mathrm{kg}$ in Mojokerto. In both of the two regions, the Fe concentrations in diets showed a high level. The low liver $\mathrm{Cu}$ concentrations in Malang and Mojokerto were probably due to the high $\mathrm{Fe}$ concentrations in diets.

McDowell et al. (1983) recommended that the critical level of plasma $\mathrm{Cu}$ concentration was 0.65 $\mu \mathrm{g} / \mathrm{ml}$. The $\mathrm{Cu}$ concentrations of all plasma samples in Jonggol were below the critical level and the lowest $\mathrm{Cu}$ concentration was only $0.09 \mu \mathrm{g} / \mathrm{ml}$. NRC (1984) recommended that the Cu requirement for beef cattle was 4-10 ppm. The Cu level in diets from Jonggol was regarded as marginal because most of the diet samples ranged from 4 to $10 \mathrm{mg} / \mathrm{kg}$ (table 1). Campbell et al. (1974) reported that the plasma $\mathrm{Cu}$ concentrations in calves, which were fed with the diet containing $1,981 \mathrm{mg} / \mathrm{kg}$ of $\mathrm{Fe}$, decreased to $0.33 \mu \mathrm{g} / \mathrm{ml}$. The mean $\mathrm{Fe}$ concentration in diets from Jonggol were $2,960 \mathrm{ppm}$ in the rainy season and $1,020 \mathrm{mg} / \mathrm{kg}$ in the dry season (table 2). It is likely that not only the marginal $\mathrm{Cu}$ concentration but also the high $\mathrm{Fe}$ concentration in diets caused the low plasma $\mathrm{Cu}$ concentrations of cattle from Jonggol.

Ward (1978) indicated that a high level of Mo $(>20 \mathrm{mg} / \mathrm{kg}$ ) or a narrow $\mathrm{Cu}:$ Mo ratio $(<2.0)$ induced $\mathrm{Cu}$ deficiency in cattle. In the present study, the maximum Mo concentration in diet was $3.06 \mathrm{mg} / \mathrm{kg}$ and no sample showed a $\mathrm{Cu}: \mathrm{Mo}$ ratio below 2.0 (table 1). Underwood (1971) reported that the liver Mo concentrations of cattle was $2-4 \mathrm{mg} / \mathrm{kg}$ on normal diets. Most of the liver samples from Malang and Mojokerto ranged from 2 to $4 \mathrm{mg} / \mathrm{kg}$. Judging from the Mo concentrations in diet and liver samples, the Mo concentrations in diets from three regions were normal and were not likely to influence the $\mathrm{Cu}$ metabolism in cattle.
The range of $\mathrm{Zn}$ requirement for beef cattle is from 20 to $40 \mathrm{mg} / \mathrm{kg}$ according to the NRC standard (1984). In the present study, $42 \%$ of the diet samples showed $\mathrm{Zn}$ concentrations between 20 and $40 \mathrm{mg} / \mathrm{kg}$ and $7 \%$ of the samples showed $\mathrm{Zn}$ concentrations below $20 \mathrm{mg} / \mathrm{kg}$. McDowell et al. (1983) recommended that a plasma $\mathrm{Zn}$ concentration of $0.6-0.8 \mu \mathrm{g} / \mathrm{ml}$ was a indicator of $\mathrm{Zn}$ deficiency. Twenty six percent of the plasma samples showed $\mathrm{Zn}$ concentration between 0.6 and 0.8 $\mu \mathrm{g} / \mathrm{ml}$ and $4 \%$ of the samples showed $\mathrm{Zn}$ concentrations below $0.6 \mu \mathrm{g} / \mathrm{ml}$ in the three regions. Judging from the $\mathrm{Zn}$ concentrations in diets and plasma, the $\mathrm{Zn}$ status of cattle in three regions was close to the borderline or was deficient.

McDowell et al. (1983) concluded that Mn deficiency can be detected by the combination of diet and liver analyses. The overall mean of $\mathrm{Mn}$ concentrations in diets was much higher than the NRC standard requirement (1984) of $20-50 \mathrm{mg} /$ $\mathrm{kg}$ for beef cattle and all the liver samples except one exceeded the critical level of $6 \mathrm{mg} / \mathrm{kg} \mathrm{recom-}$ mended by McDowell et al. (1983). The Mn concentrations in diet and liver samples indicated that the Mn intake of cattle was sufficient in the three regions.

The present study indicated that the cattle in Jonggol, Malang and Mojokerto were likely to be low in $\mathrm{Cu}$ status judging from the low plasma $\mathrm{Cu}$ concentrations in Jonggol and the low liver $\mathrm{Cu}$ concentrations in Malang and Mojokerto. One of the causes of low plasma $\mathrm{Cu}$ concentrations in Jonggol was likely due to the low $\mathrm{Cu}$ concentrations in diets, moreover, the high $\mathrm{Fe}$ concentrations in diets may have influenced the plasma $\mathrm{Cu}$ level in Jonggol. The high $\mathrm{Fe}$ concentration in diet was likely to decrease the liver Cu concentrations in Malang and Mojokerto. Standish et al. (1969) indicated that a concentration of $400 \mathrm{mg} /$ $\mathrm{kg} \mathrm{Fe}$ in diets resulted in not only decreasing $\mathrm{Cu}^{\prime}$ concentrations in livers but also depressing feed intake and average daily gain. It is obscure that such symptoms of $\mathrm{Fe}$ excess are observed in the three regions in Java. However, special attention should be paid to the low $\mathrm{Cu}$ and excessive $\mathrm{Fe}$ concentrations in diets of cattle in Java, Indonesia.

\section{Acknowledgements}

The authors gratefully acknowledge the Bogor Agricultural University for advice and co-operation 
on this study. The study was supported by a grantin aid for scientific research (No. 62045019) from the Ministry of Education, Science and Culture of Japan.

\section{Literature Cited}

Barr, A. J., J. H. Goodnight, J. P. Stall and J. T. Helwig. 1985. SAS User's Guide. Statistics. Version 5 edition. North Carolina State Univ., Raleigh, NC. pp. 433-506.

Campbell, A. G., M. R. Coup, W. H. Bishop and D. E. Wright. 1974. Effect of elevated iron intake on the copper status of grazing cattle. NZ. Journal of Agricultural Research. 17:393-399.

Harada, H., R. Kawashima and N. Usami. 1976. Effect of feeding deodorized poultry droppings which contained high level of iron on tissue mineral composition of fattening steers. Bulletin of the Faculty of Agriculture, University of Miyazaki. 23:1-8.

Hayashi, M., Y. Ogura, I. Koike, N. Yabe, R. Mudigdo and A. Peranginangin. 1985. Mineral concentrations in serum of cattle and buffalo and some herbages collected from pastures around Medan in Indonesia. Bull. Natl. Inst. Anim. Health. 88:35-41.

Islam, M. A. and M. A. Elahi. 1954. Reversion of ferric iron to ferrous iron under water-logged conditions and its relation to available phosphorus. J. Agric. Sci., Camb. 45:1-2.

Kumagai, H., N. Ishida, M. Katsumata, H. Yano, R. Kawashima and J. Jachja. 1990. A study on nutri- tional status of macro minerals of cattle in Java in Indonesia. Asian-Australasian Journal of Animal Sciences 3(1):7-13.

Leech, A. and I. Thornton. 1987. The elements in soils and pasture herbage on farms with bovine hypocupraemia. J. Agric. Sci., Camb. 108:591-597.

McDowell, L. R., J. H. Conrad, G. L. Ellis and J. K. Loosli. 1983. Minerals for grazing ruminants in tropical regions. Institute of Food and Agricultural Sciences, University of Florida, Gainesville, pp.30-54.

NRC. 1984. Nutrient Requirements of Beef Cattle. Sixth revised edition. National Academy Press, Washington, D.C. pp.11-25.

Standish, J. F., C. B. Ammerman, C. F. Simpson, F. C. Neal and A. Z. Palmer. 1969. Influence of graded levels of dietary iron, as ferrous sulfate, on performance and tissue mineral composition of steers. $\mathbf{J}$. Anim. Sci. 29:496-503.

Takahashi, T. 1978. Problems on inorganic nutritional status of soil and pasture in Japanese grassland. 3 . Iron, manganese and zinc. A riview (in Japanese). J. Japan. Grassl. Sci. 24:74-82.

Underwood, E. J. 1971. Trace Elements in human and animal nutrition. Third edition Academic Press, London. pp.119.

Vijchulata, P., S. Chipadpanich and L. R. McDowell. 1983. Mineral status of cattle raised in the villages of Central Thailand. Tropical Animal Production. 8:131-137.

Ward, G. M. 1978. Molybdenum toxicity and hypocuprosis in ruminants a review. J. Anim. Sci. 46:10781085 . 